\title{
Genetic-Quantitative Uni- and Bi-Trait Analysis for Growth Traits in the Colombian Creole Breed Blanco Orejinegro (BON)
}

\section{Marisol Londoño-Gil ( $\square$ malondonogi@unal.edu.co)}

Universidad Nacional de Colombia Sede Medellín: Universidad Nacional de Colombia Sede Medellin https://orcid.org/0000-0001-6522-5567

\section{Juan Carlos Rincón Flórez}

Universidad Nacional de Colombia Campus Palmira

\section{Albeiro López-Herrera}

Universidad Nacional de Colombia Sede Medellín: Universidad Nacional de Colombia Sede Medellin

Luis Gabriel Gonzalez-Herrera

Universidad Nacional de Colombia Sede Medellín: Universidad Nacional de Colombia Sede Medellin

\section{Research Article}

Keywords: productive performance, quantitative analysis, animal breeding, genetic parameters, animal genetic resource

Posted Date: December 8th, 2021

DOI: https://doi.org/10.21203/rs.3.rs-1125146/v1

License: (c) (1) This work is licensed under a Creative Commons Attribution 4.0 International License. Read Full License 
1 Genetic-quantitative uni- and bi-trait analysis for growth traits in the Colombian creole breed Blanco

2 Orejinegro $(\mathrm{BON})$

3

4 Marisol Londoño-Gil ${ }^{1,3 *}$, Juan Carlos Rincón Flórez ${ }^{2,4}$, Albeiro López-Herrera ${ }^{1,5}$, Luis Gabriel Gonzalez-

$5 \quad$ Herrera $^{1,6}$

6

$7 \quad{ }^{1}$ Grupo de investigación Biodiversidad y Genética Molecular (BIOGEM), Universidad Nacional de Colombia 8 sede Medellín. Carrera 65 N 59A-110, PC 050034, Medellín, Colombia.

$9{ }^{2}$ Grupo de investigación Biodiversidad y Genética Molecular (BIOGEM), Universidad Nacional de Colombia 10 sede Palmira. Carrera 32 N 12 - 00, PC 763352, Palmira, Colombia

$11 \quad{ }^{3}$ ORCID: 0000-0001-6522-5567

12 ' ORCID: 0000-0002-6769-6407

13 5 ORCID: 0000-0003-1444-3470

$14 \quad{ }^{6}$ ORCID: 0000-0001-7156-9753

15 *Corresponding author: malondonogi@ unal.edu.co

16

Acknowledgements

The authors thank to the Ministerio de Ciencia, Tecnología e Innovación de Colombia - Minciencias, Universidad Nacional de Colombia - Sede Medellín, and Universidad Tecnológica de Pereira, for the support provided for this project [Minciencias code 110177658049, and Contract number P44842-015-2018, 2018]. 


\section{Abstract}

The Blanco Orejinegro (BON) is a Colombian creole cattle breed that is not genetically well characterized for growth traits. The aim of this work was to estimate genetic parameters for birth weight (BW), weaning weight (WW), yearling weight (YW), daily weight gain between birth and weaning (DWG), time to reach $120 \mathrm{~kg}$ of live weight (T120), and time to reach $60 \%$ of adult weight (T60\%), and establish the selection criteria for growth traits in the BON population of Colombia. Genealogical and phenotypic information for BW, WW, YW, DWG, T120, and $\mathrm{T} 60 \%$ traits of BON animals from 14 Colombian herds were used. These traits were analyzed with the AIREML method in a uni- and bi-trait animal model including the maternal effect for BW, WW, DWG, and T120. The direct heritability estimates values were $0.22 \pm 0.059(\mathrm{BW}), 0.20 \pm 0.057(\mathrm{WW}), 0.20 \pm 0.153(\mathrm{YW}), 0.17 \pm$ 0.07 (DWG), 0.26 (T120), and $0.44 \pm 0.03$ (T60\%). The maternal heritability estimates values were $0.14 \pm 0.040$ $(\mathrm{BW}), 0.15 \pm 0.039(\mathrm{WW}), 0.25 \pm 0.06(\mathrm{DWG})$, and $0.16(\mathrm{~T} 120)$. The direct genetic correlations were high $(>|0.60|)$ among all the traits, except between T60\% with BW, WW, YW, and DWG (ranged from -0.02 to -0.51 ), all in a favorable direction. The results showed that there is genetic variation in the growth traits associated with the additive genetic effect and they might respond to selection processes. Furthermore, genetic gains would improve through selection, especially for YW and T60\% when WW is used as criterion.

keywords: productive performance, quantitative analysis, animal breeding, genetic parameters, animal genetic resource.

\section{Introduction}

The Colombian Creole cattle breed Blanco Orejinegro (BON) has a natural selection process of $\sim 500$ years to the Colombian tropic conditions. Phenotypically, has a white coat and black ears, skin, and snout (López-Herrera et al., 2001). Its economic importance lies in its rusticity, longevity, ability to reproduce, survive, and because it is a triple purpose animal (milk, meat, and work) (Bedoya et al., 2001; López-Herrera et al., 2001)

Despite its good performance for some traits, for 2018 there were only 2003 pure BON animals (FAO, 2018). The information available about the genetic bases controlling aspects related to its growth parameters is limited. Furthermore, there is not information about the genetic variability in the BON population, that allow to establish if selection can be made in the breed. Gallego et al., (2006), Cañas et al., (2008), and Ramírez-Toro et al., (2019), have carried out studies genetically evaluating the breed, with information from a single herd in each case, preventing the generalization of their results to the entire population.

Studying the growth traits in BON cattle is necessary since usually, in beef cattle, these traits are considered selection criteria (Chud et al., 2014). Besides, they can be easily estimated as they are calculated directly with 
phenotypic data and are measured several times in the animal's life as part of the routine management. Likewise, due to their heritability estimates of moderate to high magnitude, have a good response to direct selection (Chud et al., 2014; Moreira et al., 2015)

Therefore, the aim of this work was to estimate genetic parameters for the growth traits birth weight (BW), weaning weight (WW), yearling weight (YW), daily weight gain between birth and weaning (DWG), time to reach $120 \mathrm{~kg}$ of live weight (T120), and time to reach $60 \%$ of adult weight (T60\%), of the Blanco Orejinegro (BON) breed from Colombia, to verify if there is sufficient genetic variability to make selection and determine the selection criteria to be utilized - according to genetic correlations - to provide selection tools for better performance and most intensive use of the breed.

\section{Materials and methods}

The Ethics Committee for the Care and Use of Animals of Universidad Nacional de Colombia, Medellín campus, has approved this work [CICUA-005 of 2016].

Data

Historical phenotypic and pedigree data (from 2000 to 2018), belonging to 8 Colombian BON herds located in the states of Antioquia, Caldas, Meta, and Risaralda were used. Each herd had its own edaphoclimatic and pasture conditions. The growth traits considered were BW, WW, YW, DWG, T120, T60\%. The traits T120 and T60\% were calculated from the growth curve parameters obtained by the Brody model: $Y_{i j}=\beta_{0}+\left(1-\beta_{1} e^{-\beta_{2} t}\right)$ cited by Dominguez Viveros et al., (2017), using the consecutive weights in the animal's life, and the BW as a starting point. Animals with at least four weighings and 800 days of age were employed. In this model, $Y_{i j}$ corresponds to the $\mathrm{j}$-th weight of the $\mathrm{i}$-th animal at a time $(t) ; \beta_{0}$ corresponds to the asymptotic value when $t$ tends to infinity, $\beta_{1}$ corresponds to an adjustment parameter when $Y_{i j} \neq 0$, and when $Y_{i j} \neq 0, \beta_{2}$ is the growth rate; expressed as a proportion of the total weight. Finally, $t$ is the age in days.

T120 was obtained by clearing the time from Brody's equation, as follows:

$$
T(120)=\frac{\log \left(1-\left(\frac{120}{\beta_{0}}\right)\right)}{\beta_{2}}+\frac{\left(\log \left(\frac{1}{\beta_{1}}\right)\right)}{-\beta_{2}}
$$

The equation of Ramírez et al., (2009) was used to calculate the time to reach $60 \%$ of adult weight, as follows:

$$
T 60 \%=\frac{\log \left(\beta_{0}-\left(\beta_{0} * 0,6\right)\right)-\log \left(\beta_{0} * \beta_{1}\right)}{-\beta_{2}}
$$


The information was depurated using the R Project program (R Core Team, 2020), where records with data above or below three standard deviations according to the mean of each trait were eliminated. Moreover, animal records that had complete information related to the identification of the animal, dam, and herd, calving number, sex, date, BW, and BW and YW, were included in the analyzes. The final dataset included 3218 records for BW, 2265 for WW, 496 for YW, 2287 for DWG, 325 for T120, and 408 records for T60\%.

\section{Model}

Table 1 shows the data structure used for the growth traits genetic analyzes in the BON cattle. Although pedigree individuals were 7799 , from 14 herds, there was a reduction in the number of animals in the kinship matrix, according to the connectivity and animals number associated with phenotypic records.

For each trait, the fixed effects were contemporary group (CG - composed by herd, sex and weighing year for BW, WW, YW and DWG, and herd and year for T60\% and T120), weighing season distributed in four periods (dry season 1: January to March, rainy season 1: April to June, dry season 2: July to September, rainy season 2: October to December), calving number (CN: 1-7 with 7, grouping $\geq 7$ calvings), sex (T120 and T60\%), and weaning or yearling age as covariates for the WW and YW traits, respectively. As random effects, direct and maternal additive genetic effects were considered.

A uni-trait animal model was used to estimate genetic parameters; in addition, bi-trait analyses was performed to estimate the genetic and phenotypic correlations between the BW, WW, YW, DWG, T120, and T60\% traits. The genetic parameters were estimated through the frequentist Average Information Restricted Maximum Likelihood (AIREML) methodology, using the Wombat software (Karin Meyer, 2007), with a $10^{-9}$ convergence criterion. For the BW, WW, DWG, and T120 traits, maternal additive genetic effects were included. Difficulties in reaching the convergence criterion for direct $\left(h_{d}^{2}\right)$ and maternal $\left(h_{m}^{2}\right)$ heritability estimates obtained through univariate analysis for trait T120 were observed, due to the limited amount of data available. Mean values obtained through a bivariate analysis were considered in this case. The general animal model used was:

$$
\mathbf{y}=\mathbf{X} \boldsymbol{\beta}+\mathbf{Z u}+\mathbf{W m}+\mathbf{e}
$$

Where, $\mathbf{y}$ is a vector of observations for each trait, $\boldsymbol{\beta}$ is a solution vector of fixed effects, and $\mathbf{u}$ is a solution vector for direct additive genetic random effects. Further, $\mathbf{m}$ is a solution vector for maternal additive genetic random effects (for BW, WW, DWG, and T120), $\mathbf{e}$ is a vector of random residuals. $\mathbf{X}, \mathbf{Z}$, and $\mathbf{W}$ are the incidence matrices associated with their respective effects for $\mathbf{y}$.

The assumptions considered for the general model were the following:

$$
\left[\mathbf{a}^{\prime} \mathbf{m}^{\prime} \mathbf{e}^{\prime}\right] \sim \mathrm{N}[0, \operatorname{Var}] ; \operatorname{Var}(\mathbf{a})=\mathbf{A} \sigma_{\mathrm{a}}^{2} ; \operatorname{Var}(\mathbf{m})=\mathbf{A} \sigma_{\mathrm{m}}^{2} ; \operatorname{Var}(\mathbf{e})=\mathbf{I} \sigma_{\mathrm{e}}^{2} ; \operatorname{Cov}(\mathrm{a}, \mathrm{m})=\mathrm{A} \sigma_{\mathrm{am}}^{2}
$$


Where $\sigma_{\mathrm{a}}^{2}$ is the additive genetic variance, $\sigma_{\mathrm{m}}^{2}$ is the maternal additive genetic variance, $\sigma_{\mathrm{e}}^{2}$ is the residual variance, and $\sigma_{\mathrm{am}}^{2}$ is the covariance between the direct additive and maternal additive genetic effects. $\mathbf{A}$ is the numerator of the additive kinship matrix, and $\mathbf{I}$ is an identity matrix. The bivariate animal model used was the one employed by Koetz Junior et al., (2019).

The genetic progress and the expected correlated response for the studied traits were also calculated, considering the same selection intensity (equal to 1 ). The formulas used were the following:

$$
\Delta G=h_{1}^{2} i \sigma_{1} \quad C R_{2}=r_{a} h_{1} h_{2} i_{1} \sigma_{2} \quad R E=\left(C R_{2} / \Delta G\right) \times 100
$$

Where, $\Delta G$ is the genetic progress by direct selection for each trait (BW, WW, YW, DWG, T120, and T60\%), $h_{i}^{2}$ is the heritability for the $i$-th trait, $i$ is the selection intensity for the trait in standard deviation units, and $\sigma_{i}$ is the phenotypic standard deviation for the $i$-th trait. $C R_{2}$ is the correlated response for the $i$-th trait when selected for the $j$-th trait, $r_{a}$ is the genetic correlation between the traits, $h_{i}$ is the square root of the heritability for the i-th trait and $i_{i}$ is the selection intensity for the $\mathrm{i}$-th trait. $R E$ is the relative efficiency of the selection.

\section{Results}

According to the genealogy information (7799 individuals), the total inbred animals in the BON population ( $F>0$ ) was 3705 , and the inbreeding coefficient mean was $4.41 \%$, although considering only the population of inbred animals, it was $9.29 \%$.

The genetic parameters of direct $\left(h_{d}^{2}\right)$ and maternal heritabilities $\left(h_{m}^{2}\right)$ and correlations between direct and maternal additive genetic effects $\left(\mathrm{r}_{\mathrm{am}}\right)$ are shown in Table 2. A large proportion of the growth traits variation was associated with direct additive genetic variance, finding $h_{d}^{2}$ estimates of $0.22 \pm 0.059$ (BW), $0.20 \pm 0.057$ (WW), $0.17 \pm 0.07$ (DWG), $0.202 \pm 0.153$ (YW), 0.26 (T120), and $0.44 \pm 0.03$ (T60\%). Another significant proportion of the variation for the pre-weaning traits was associated with maternal additive genetic variance, thus the $h_{m}^{2}$ estimates were $0.14 \pm 0.040$ (BW), $0.15 \pm 0.039$ (WW), $0.25 \pm 0.06$ (DWG), and 0.15 (T120). The correlations between direct and maternal additive genetic effects ranged between -0.39 and 0.19

The genetic and phenotypic correlations between the growth traits analyzed in the BON breed from different regions of the Colombian tropics are presented in Table 3. The genetic correlations for the direct additive genetic effect between the $\mathrm{BW}, \mathrm{WW}, \mathrm{YW}$, and DWG traits were high and positive, varying from 0.82 to 0.99 . Between the BW, WW, YW, DWG traits and T120\%, were high and negative (ranging from-1 to -0.67 ). Concerning to $\mathrm{T} 60 \%$ and the $\mathrm{BW}$, the correlation was -0.02 , being classified as null. Between $\mathrm{T} 60 \%$ and $\mathrm{WW}$, $\mathrm{YW}$, and DWG traits, the correlations were negative and ranged from -0.51 to -0.32 , being classified as moderate 
and would have a favorable impact for the T60\% trait. Finally, the genetic correlation between T120 and T60\% was high (0.60),

The response to selection is presented in the Table 4. For most cases, the best option is to use T120 or WW as a selection criterion.

\section{Discussion}

The population inbreeding coefficient mean found was lower than Cañas et al., (2008) reported in a single BON herd $(24.5 \%)$. However, the population mean was moderate; this should be highlighted when considering the small size of the BON population that currently exists (Martínez et al., 2012). Therefore, the magnitude of this coefficient must be controlled within the BON population through strategies, such as directed mating that considers the degree of kinship and inbreeding of individuals.

In the genetic parameters estimates, the results indicate the existence of sufficient additive genetic variability, in which the growth traits would exhibit selection response. Nevertheless, the maternal heritability value must be interpreted carefully, since it was not possible to separate the permanent environment effect; therefore, the maternal additive genetic variance could be overestimated. These results indicate that the growth traits evaluated before weaning in BON breed can respond to selection for both direct and maternal genetic effects, considering their genetic correlations which were of low magnitude, probably because very few genes influence direct and maternal additive genetic effects simultaneously, also are indicating the lack of correlation, given by a high variation between sires and dams, either due to a higher genetic variance or confusion between the environmental effects (Meyer, 1992; Vergara et al., 2009). On the other hand, post-weaning traits should be selected based on their direct breeding values.

Fow BW, the $h_{d}^{2}$ estimate was lower than the ones found for BW by Gallego et al., (2006) and Ramírez-Toro et al., (2019) of $0.38 \pm 0.017$ and 0.36 , respectively, in BON breed populations from a single herd. The $h_{m}^{2}$ for this trait was higher than the reported by Gallego et al., (2006)with a value of $0.03 \pm 0.015$, and lower than the found by Ramírez-Toro et al., (2019) of 0.20 . This difference may be due to the variable number of herds under study and the phenotype and pedigree information of the various herds

The $h_{d}^{2}$ values for WW of this research are similar to those found in the BON breed by Gallego et al., (2006) of $0.18 \pm 0.022$ and Ramírez-Toro et al. (2019) of 0.17 , but lower than those found by Cañas et al. (2008) of 0.63 \pm 0.36 . The $h_{m}^{2}$ estimate is superior to the ones found by Gallego et al. (2006) of $0.0599 \pm 0.025$ and RamírezToro et al. (2019) of 0.11, and lower than the one found by Cañas et al. (2008) of $0.22 \pm 0.19$. This may indicate that the dams of the current BON breed population from Colombia have a maternal effect on the WW of their 
calves, higher than the one found previously in the studies mentioned above. This may be due to postnatal influences, mainly nutritional, such as milk production (Quijano \& Echeverri-Zuluaga, 2015). Negative and very high correlations between $h_{d}^{2}$ and $h_{m}^{2}$ of $-0.78 \pm 0.21$ in a single Colombian BON breed herd was reported by Cañas et al. (2008), contrary to what was found in the current study.

In the DWG trait, the $h_{d}^{2}$ and $h_{m}^{2}$ estimates indicate that the genetic component is influenced by the growth ability of the offspring and the ability of the BON dams to raise a calf; however, the maternal genetic effect is higher than the direct one on the total phenotypic variance. This may be due to the maternal effect given by the milk production of the dam that influences more the variability of the trait at this growth stage. In this sense, it is widely known that the dam is responsible for $60 \%$ of the weaning growth (Amaral et al., 2014). In Nelore breed, lower estimates of direct heritability $(0.12 \pm 0.04)$ and higher estimates of maternal heritability $(0.29 \pm 0.09)$ have been found, with a high and negative correlation between the direct and maternal genetic effect of -0.77 (Rocha et al., 2003). For these authors, the maternal effect is much higher than the direct one, as in the current study, explained by the high dependence of the calf on the dam between birth and weaning.

For YW, similar results were found in Brahman (0.22 \pm 0.02$)$ (Manuel et al., 2019) and in Nelore breed, these the estimates varied between 0.17 and 0.44 (Moreira et al., 2015; Teixeira et al., 2018; Koetz Junior et al., 2019). In the BON breed, there are no reports in the literature of genetic parameters for YW. This trait is economically important as it shows the genetic potential of the animal to develop and gain weight (Hernández-Hernández et al., 2015).

The $h_{d}^{2}$ and $h_{m}^{2}$ for T120 have not been previously reported in BON breed. This trait measures growth speed and is important because it can be used as a selection criterion for the growth precocity or earliness of the animals and the maternal ability to produce milk. This shows that shorter the time to reach $120 \mathrm{~kg}$, animal precocity and maternal ability are greater, with higher weights expected at future ages as weaning weight (Garnero et al., 2001a), and the animals have the potential to respond to selection for precocious growth (Santana et al., 2017). There are reports of growth speed of days to reach $160 \mathrm{~kg}$ (T160) and $180 \mathrm{~kg}$ (T180) in Nelore breed, where estimates of direct heritability for T160 vary between 0.12 and 0.42 , and maternal heritability from 0.0 to 0.07 (Garnero et al., 2001a;Garnero et al., 2001b; Henrique et al., 2005), and for T180, the values recorded were 0.45 and 0.04 , respectively (Santana et al., 2017).

For T60\% trait, the animals reach $60 \%$ of adult live weight at around 18 months, but with high variability for the animals sampled. Therefore, care must be taken when interpreting this result, given the low amount of data. It is expected that as new information is obtained for the trait, the estimates will be more accurate. This is an indicator trait of growth speed and sexual maturity, since the faster the growth rate, the animal will reach puberty faster. 
This precocity can lead to better reproductive parameters of the animal and greater longevity or useful life of the animals in the herd (Ramírez et al., 2009). Similar results have been found in Brahman breed (0.42) for the puberty age and in Indubrasil breed, and Nelore breed $(0.35 \pm 0.05)$ for weight at 550 days; these are considered estimates of moderate heritability for the trait (Vargas et al., 1998; De Souza et al., 2018). Higher estimates for this trait (0.75) have also been reported in Nelore breed (Gonçalves et al., 2011).

The genetic correlations for the direct additive genetic effect between the BW, WW, YW, and DWG traits indicate that a large part of the genes with additive action that influence one of the traits also influence the others. Furthermore, animals with superior genetic merit for BW will also have higher genetic merit for DWG, and even higher genetic merit at weaning and at one year of age, and vice versa. These results indicate that selecting individuals with genetic potential for higher birth weight will be reflected in a correlated response in the other traits. Thus, the selection of young individuals may reduce the generational interval, showing a faster response to selection. These results are superior to the low genetic correlations reported between BW and WW traits of 0.30 adjusted at 240 days in BON breed by Ramírez-Toro et al., (2019). In the Costeño Con Cuernos and Romosinuano creole breeds, high correlations have been reported between pre-weaning traits, like what was found in the current study (Martínez \& Pérez, 2006; Martínez Rocha et al., 2018). Similar genetic correlations have also been found by Martins et al., (2000) in Nelore breed.

The genetic correlations for the direct genetic effect between the BW, WW, YW, and DWG traits with $\mathrm{T} 120 \%$, indicate that a large part of the genes with additive action that make individuals show positive genetic merit for those traits, influence these individuals to present favorable genetic merit with negative breeding values for T120, which is desirable in beef cattle. The contrary was found by Koetz Júnior et al., (2017) and Santana et al., (2017), where the genetic correlations were high and positive between the speed of growth traits (T180 or T160) with daily weight gains before and after weaning.

For $\mathrm{T} 60 \%$ and $\mathrm{BW}$, the genetic correlations suggests that genes that affect the $\mathrm{BW}$ of differ slightly from those responsible for the growth of genes involved in T60\%, these results indicate that the selection of animals for BW would have essentially no impact for T60\%. A genetic correlation close to zero (-0.04) between pre and postweaning traits was also reported by Vergara et al., (2009) in cattle crossbred with BON.

The genetic correlation between T120 and T60\% shows that a large part of additive genes that are expressed in the pre-weaning growth speed trait T120 are still being expressed in another post-weaning growth speed trait $(\mathrm{T} 60 \%)$ that is indicative of sexual maturity and precocity. A moderate genetic correlation (0.23) was obtained in Nelore breed by Santana et al., (2017) between the pre-weaning trait T180 (days to reach $180 \mathrm{~kg}$ ) and the postweaning trait T300 (days to reach $300 \mathrm{~kg}$ ). The analysis of these results suggests that the traits should not be used 
simultaneously in selection indices since, due to the high genetic correlations found, selection for one will cause a similar magnitude-correlated response in the other.

The phenotypic correlations exhibited a similar behavior regarding the signs of the genetic correlations, but different in relation to the magnitude. This difference is expected, since the phenotypic correlation has an intrinsic combination of additive, non-additive, and environmental genetic effects affecting the trait (Quijano \& EcheverriZuluaga, 2015).

According to the response to selection analysis, selection for T120 might be the better option when looking for genetic progress in the other traits, as it has better-correlated responses $\left(\mathrm{CR}_{2}\right)$. Therefore, moderate responses correlated to selection will be expected for WW (+7.26 kg), YW (+8.50 kg), DWG (+0.028 kg/day), and T60\% (49 days). Nevertheless, caution should be exercised when using the response to selection data, since the estimates found for the T120 trait showed difficulties when converging, given the limited number of phenotypic observations. Consequently, for all traits, it is recommended to use WW as a selection criterion, since it is a trait from which a relative efficiency to selection (RE) close to and even higher than $100 \%$ is expected when it is used as a selection criterion to obtain genetic progress, more similar to in the case of carrying out a direct selection $(0.62$ $\mathrm{kg}, 7.30 \mathrm{~kg}, 0.025 \mathrm{~kg} /$ day, -6.11 , and -26.13 days for BW, YW, DWG, T120, and T60\% respectively). Besides, WW is a trait recorded in most herds and that the producer has at hand to carry out selection. The contrary occurs with T120, which must be calculated and implies new procedures that producers must carry out to have information for this trait.

These results are different from those found by Garnero et al. (2001a) in the Nelore breed, where the trait weight at 550 days showed a higher correlated response compared to weights at lower ages or times to reach a certain weight. For authors as Ortiz Peña et al., (2004), when using T160 as a selection criterion, a higher response correlated to selecting pre-weaning traits is obtained. They even recommend this type of selection criterion, since, in animal industries that use traits like T160 (time to reach certain weights), they have achieved a remarkable degree of production uniformity, allowing all in-all out systems.

Therefore, these results showed that a large proportion of the variation of the traits was associated with the direct additive genetic term, and another large percentage was associated with the maternal genetic term, except for $\mathrm{YW}$ and $\mathrm{T} 60 \%$. The growth traits assessed in this study exhibited significant genetic variability and could respond appropriately to the selection process if this is done based on breeding values. High correlated responses are expected through selection for growth traits in BON breed based on genetic breeding, especially for YW and T60\% when WW is used as a selection criterion. 


\section{Declarations}

\section{Conflicts of interest}

The authors of this work declare that there are no conflicts of interest that jeopardize the validity of the results obtained.

\section{Funding}

This work was funded by the Ministerio de Ciencia Tecnología e Innovación de Colombia (Minciencias), Universidad Nacional de Colombia - Medellín campus, and Universidad Tecnológica de Pereira, [Contract number P44842-015-2018].

\section{Ethical approval}

The study complies with current Colombian laws. This work was approved by a research ethics committee at the Universidad Nacional de Colombia - Medellín campus, CICUA 005 of 2016, and followed all applicable international, national, and institutional guidelines for animal care and

\section{Consent to participate}

Herd and animal owners signed a consent to participate in the project that generated this article.

\section{Consent to publish}

The owners of the herds and animals signed a consent so that the data could be published, provided it was done anonymously.

\section{Availability of data and material}

The data sets generated and/or analyzed during the current study are available through the corresponding author upon reasonable request.

\section{Code availability}

The code generated during this study is available through the corresponding author upon reasonable request.

\section{Authors' contributions}

All authors contributed to the conception and design of the study. The preparation of the material, the data collection, and the analysis were carried out by all the authors. Marisol Londoño Gil wrote the first draft of the manuscript, and the other authors made their contributions on later versions. All authors read and approved the final manuscript.

\section{References}

Amaral, R. dos S., Carneiro, P.L.S., Martins Filho, R., Ambrosini, D.P., and Malhado, C.H.M., 2014. Tendências, parâmetros fenotípicos e genéticos de características de crescimento em bovinos Nelore mocho do Nordeste brasileiro, Revista Brasileira de Saúde e Produção Animal, 15, 261--271. https://doi.org/10.1590/S1519- 
Bedoya, G., Carvajal, L.G., Moreno, F.L., Davies, S., Derr, J., Ossa, J., and Ruiz, A., 2001. Estructura molecular y poblacional del ganado criollo Colombiano (GCC), Revista Colombiana de Ciencias Pecuarias, 14, 109-120.

Cañas, J.J., Ramírez, J., Arboleda, O., Ochoa, J., Vergara, O., and Cerón, M., 2008. Estimación de parámetros genéticos para peso al destete en ganado blanco orejinegro (BON) en el noroccidente colombiano, Revista MVZ Córdoba, 13, 1138--1145. https://doi.org/10.21897/RMVZ.405

Chud, T.C.S., Caetano, S.L., Buzanskas, M.E., Grossi, D.A., Guidolin, D.G.F., Nascimento, G.B., Rosa, J.O.,

Lôbo, R.B., and Munari, D.P., 2014. Genetic analysis for gestation length, birth weight, weaning weight, and accumulated productivity in Nellore beef cattle, Livestock Science, 170, 16--21. https://doi.org/10.1016/j.livsci.2014.09.024

De Souza, J.C., Gonçalves de Resende, M.P., Campos da Silva, L.O., Falci Mota, M., Freitas, J.A., Gondo, A., and Rosana, M. da S., 2018. Parâmetros e tendências genéticas para peso ao sobreano de animais Nelore criados no estado do Paraná, Brasil, Revista Colombiana de Ciencia Animal - RECIA, $10,68$. https://doi.org/10.24188/recia.v10.n1.2018.632

Dominguez Viveros, J., Urbina-Valenzuela, A.R., Palacios-Espinoza, A., Callejas-Juárez, N., Ortega-Gutiérrez, J.Á., Espinoza-Villavicencio, J.L., Padrón-Quintero, Y., and Rodríguez-Castro, M., 2017. Caracterización del crecimiento de bovinos cebú en pruebas de comportamiento en pastoreo, Ecosistemas y Recursos Agropecuarios, 4, 341--348. https://doi.org/10.19136/era.a4n11.1149

FAO, Organización de las Naciones Unidas para la Alimentación y la Agricultura, 2018. Sistema de Información sobre la Diversidad de los Animales Domésticos (DAD-IS): Blanco Orejinegro / Colombia (Cattle). Blanco Orejinegro / Colombia (Cattle). On http://www.fao.org/dad-is/es/, Accessed 23 Nov 2021

Gallego, J.L., Martínez, R.A., and Moreno, F.L., 2006. Índice de consanguinidad y caracterización fenotípica y genética de la raza bovina criolla Blanco Orejinegro, Corpoica Ciencia y Tecnologia Agropecuaria, 7, 16-24.

Garnero, A. del V., Barbosa, R., Framartino, L.A., and Nunes de Oliveira, H., 2001a. Comparação entre Alguns Critérios de Seleção para Crescimento na Raça Nelore, Revista Brasilera de Zootecnia, 30, 714--718.

Garnero, A. del V, Gunski, R.J.B., Schwengber, E.B., and Lôbo, R.B., 2001b. Comparación entre criterios de selección para características de crecimiento correlacionados con edad al primer parto en la raza Nelore. Livestock Research for Rural Development, 13. http://www.lrrd.org/lrrd13/2/garn132.htm, Accessed 23 Nov 2021

Gonçalves, F.M., Pires, A.V., Pereira, I.G., Garcia, D.A., Farah, M.M., Meira, C.T., and Cruz, V.A.R., 2011. 
Avaliação genética para peso corporal em um rebanho Nelore, Arquivo Brasileiro de Medicina Veterinaria e Zootecnia, 63, 158--164. https://doi.org/10.1590/S0102-09352011000100024

Henrique, C., Malhado, M., Filho, R.M., Nonato, R., Lôbo, B., Facó, O., Maria, D., Ribeiro, M., Souza, J.C., and Maria, S., 2005. Tendências Genéticas para Características Relacionadas à Velocidade de Crescimento em Bovinos Nelore na Região Nordeste do Brasil, Revista Brasileira de Zootecnia, 34, 60--65.

Hernández-Hernández, N., Martínez-González, J., Parra-racamonte, G., Ibarra-Hinojosa, M., Briones-Encinia, F., Saldaña-Campos, P., and Ortega-Rivas, E., 2015. Non-genetic effects on growth characteristics of Brahman cattle, Revista MVZ Córdoba, 20, 4427--4435. https://doi.org/10.21897/rmvz.72

Koetz Júnior, C., Roso, V.M., Claus, L.A.M., Oliveira, R.P.L., Fávaro, P. da C., Borges, M.H.F., Barcellos, J.O.J., and Ribeiro, E.L. de A., 2017. Genetic trends for mature body weight, visual scores, and growth traits in Nellore cattle, Ciência Rural, 47, 1--6. https://doi.org/10.1590/0103-8478cr20151506

Koetz Junior, C., Roso, V.M., Fávaro, P. da C., Pereira, G.R., Borges, M.H.F., Barca Junior, F.A., Barcellos, J.O.J., and Ribeiro, E.L. de A., 2019. Heritability estimation and genetic correlations for mature weight, visual scores, and growth traits in Nellore cattle, Revista Brasileira de Zootecnia, 48. https://doi.org/10.1590/rbz4820170246

López-Herrera, A., Saldarriaga, O.A., Arango, A.E., Lopez, M.T.R., Tobon, F.N.Z., Olivera, M., Bermúdez, N.R., Bedoya, G., and Londoño, J.O., 2001. Ganado Blanco Orejinegro (BON): Una alternativa para la producción en Colombia, Revista Colombiana de Ciencias Pecuarias,14, 121--128.

Manuel, M., Cavani, L., Millen, D.D., Andrighetto, C., Lupatini, G.C., and Fonseca, R., 2019. Estimation of genetic parameters for weight traits and Kleiber Index in a Brahman cattle population, Scientia Agricola, 76, 459--462. https://doi.org/10.1590/1678-992x-2018-0062

Martínez, R.A., and Pérez, J.E., 2006. Parámetros y tendencias genéticas para características de crecimiento en el ganado criollo colombiano Romosinuano, Corpoica Ciencia y Tecnología Agropecuaria, 7, 25--32.

Martínez, R., Vásquez, R., and Gallego, J.L. (2012). Eficiencia productiva de la raza BON en el trópico colombiano. En Corpoica (Primera ed, Vol. 1). (C) Corporación Colombiana de Investigación Agropecuaria, Corpoica.

Martínez Rocha, R.E., Ramírez Valverde, R., Núñez Domínguez, R., and García Muñiz, J.G. (2018). Parámetros y tendencias genéticas de variables de crecimiento para bovinos Romosinuano en México, Nova Scientia, 10, 310--325. https://doi.org/10.21640/ns.v10i21.1595

Martins, G.A., Martins Filho, R., Lima, F. de A. M., and Lôbo, R.N.B., 2000. Influência de fatores genéticos e de meio sobre o crescimento de bovinos da raça Nelore no Estado do Maranhão, Revista Brasileira de Zootecnia, 29, 103--107. https://doi.org/10.1590/S1516-35982000000100014 
Meyer, K., 1992. Bias and sampling covariances of estimates of variance components due to maternal effects, Genetics Selection Evolution, 24, 487. https://doi.org/10.1186/1297-9686-24-6-487

Meyer, K., 2007). WOMBAT: a tool for mixed model analyses in quantitative genetics by restricted maximum likelihood (REML), Journal of Zhejiang University. Science. B., 8, 815--821. https://doi.org/10.1631/jzus.2007.B0815

Moreira, H.L., Canova, E.B., Munari, D.P., Bezerra, L.A.F., Lôbo, R.B., and Paz, C.C.P., 2015. Parâmetros genéticos para período de gestação e características de crescimento pré e pós desmame em bovinos Nelore, Boletim de Indústria Animal, 72, 130--135. https://doi.org/10.17523/bia.v72n2p130

Ortiz Peña, C.D., Carvalheiro, R., De Queiroz, S.A., and Fries, L.A., 2004. Comparison of selection criteria for pre-weaning growth traits of Nelore cattle, Livestock Production Science, 86, 163--167. https://doi.org/10.1016/S0301-6226(03)00164-7

Quijano, J. H., and Echeverri-Zuluaga, J., 2015. Genética cuantitativa aplicada al mejoramiento animal (1a ed.). Universidad Nacional de Colombia.

R Core Team., 2020. R: A Language and Environment for Statistical Computing (4.0.0). R Foundation for Statistical Computing. https://www.r-project.org, Accessed 23 Nov 2021.

Ramírez-Toro, E.J., Ocampo-Gallego, R.J., Burgos-Paz, W.O., Elzo, M.A., Martínez-Sarmiento, R.A., and CerónMuñoz, M.F., 2019. Estimación poligénica y genómico-poligénica para características de crecimiento en ganado Blanco Orejinegro (BON), Livestock Research for Rural Development, 31. http://www.lrrd.org/lrrd31/3/ceron31030.html, Accessed 23 Nov 2021.

Ramírez, E., Cerón-Muñoz, M., Herrera, A.C., Vergara, O.D., Arboleda, E.M., and Restrepo, L.F., 2009. Crecimiento de hembras cruzadas en el trópico colombiano, Revista Colombiana de Ciencias Pecuarias, 22, 642--647.

Rocha, J.L., Pimenta Filho, E.C., Ribeiro, M.N., and Martins Filho, R., 2003. Efeitos Ambientais e Genéticos sobre o Ganho em Peso Diário de Bovinos Nelore no Estado da Paraíba, Revista Brasileira de Zootecnia, 32, 325--330. https://doi.org/10.1590/S1516-35982003000200010

Santana, B.F., da Fonseca, R., Manuel, M., Mamani, G.C.M., Eler, J.P., and Ferraz, J.B.S., 2017. Viabilidade do uso de características "dias para um peso específico" em programas de melhoramento genético de bovinos da raça Nelore, Revista Brasileira de Saude e Producao Animal, 18, 260--268. https://doi.org/10.1590/S1519-99402017000200005

Teixeira, B.B., Mota, R.R., Lôbo, R.B., Da Silva, L.P., Carneiro, A.P.S., Da Silva, F.G., Caetano, G.D.C., and Silva, F.F., 2018. Genetic evaluation of growth traits in Nellore cattle through multi-trait and random regression models, Czech Journal of Animal Science, 63, 212--221. https://doi.org/10.17221/21/2017-CJAS 
389

390

391

392

393

394

Vargas, C.A., Elzo, M.A., Chase, C.C., Chenoweth, P.J., and Olson, T.A., 1998. Estimation of Genetic Parameters for Scrotal Circumference, Age at Puberty in Heifers, and Hip Height in Brahman Cattle, Journal of Animal Science, 76, 2536--2541. https://doi.org/10.2527/1998.76102536x

Vergara, O.D., Elzo, M., Ceron-Muñoz, M.F., and Arboleda, E.M., 2009. Weaning weight and post-weaning gain genetic parameters and genetic trends in a Blanco Orejinegro-Romosinuano-Angus-Zebu multibreed cattle population in Colombia, Livestock Science, 124, 156--162. https://doi.org/10.1016/j.livsci.2009.01.008 